\title{
Geospatial Data for Coal Beds in the Powder River Basin, Wyoming and Montana
}

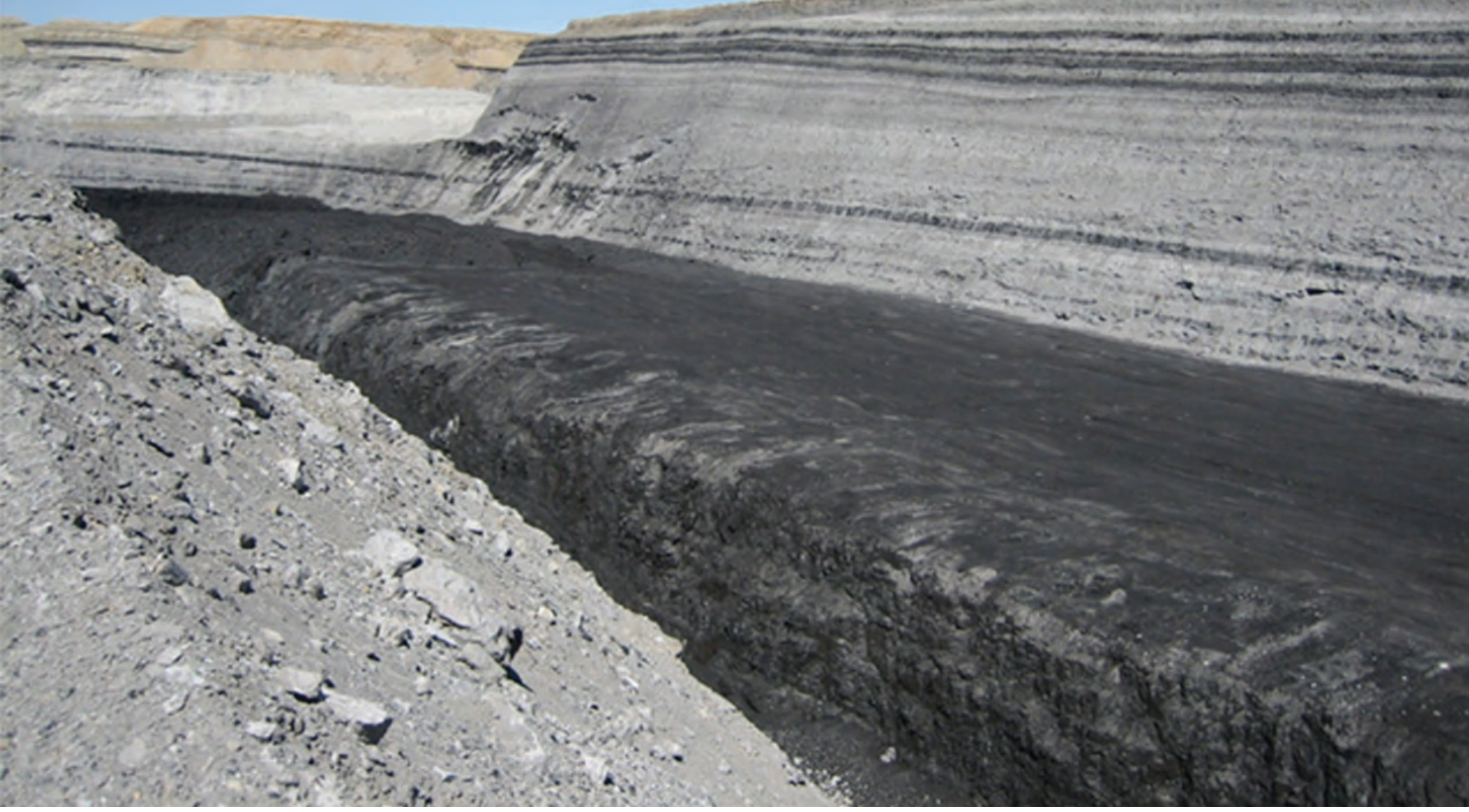

Data Series 912

U.S. Department of the Interior U.S. Geological Survey 
Cover. Coal mine in the Powder River Basin (photograph by James A. Luppens). 


\section{Geospatial Data for Coal Beds in the Powder River Basin, Wyoming and Montana}

By Scott A. Kinney, David C. Scott, Lee M. Osmonson, and James A. Luppens

Data Series 912 


\title{
U.S. Department of the Interior SALLY JEWELL, Secretary
}

\section{U.S. Geological Survey \\ Suzette M. Kimball, Acting Director}

\author{
U.S. Geological Survey, Reston, Virginia: 2015
}

For more information on the USGS - the Federal source for science about the Earth, its natural and living resources, natural hazards, and the environment—visit http://www.usgs.gov or call 1-888-ASK-USGS.

For an overview of USGS information products, including maps, imagery, and publications, visit http://www.usgs.gov/pubprod/.

Any use of trade, firm, or product names is for descriptive purposes only and does not imply endorsement by the U.S. Government.

Although this information product, for the most part, is in the public domain, it also may contain copyrighted materials as noted in the text. Permission to reproduce copyrighted items must be secured from the copyright owner.

Suggested citation:

Kinney, S.A., Scott, D.C., Osmonson, L.M., and Luppens, J.A , 2015, Geospatial data for coal beds in the Powder River Basin, Wyoming and Montana: U.S. Geological Survey Data Series 912, 7 p, GIS database, http://dx.doi.org/10.3133/ds912.

ISSN 2327-638X (online) 


\section{Contents}

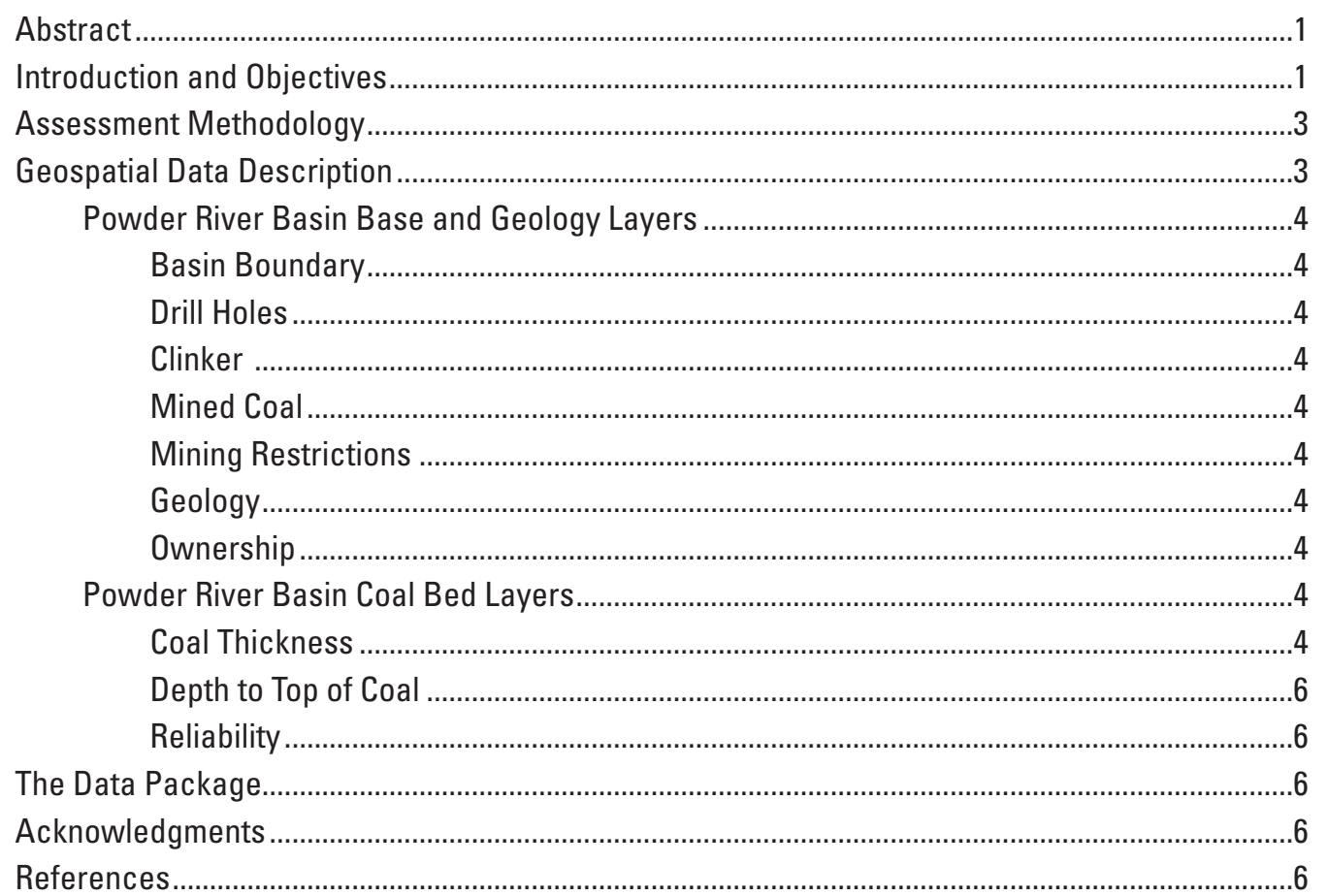

\section{Figure}

1. Map showing location of the Powder River Basin, Wyoming and Montana......................2

\section{Table}

1. List of coal bed names in chronological order, the 3-letter code used in the database, number of drill holes, and geologic formation name of the $47 \mathrm{coal}$ beds in the Powder River Basin, Wyoming and Montana. 


\section{Conversion Factors}

Inch/Pound to International System of Units

\begin{tabular}{|c|c|c|}
\hline Multiply & By & To obtain \\
\hline \multicolumn{3}{|c|}{ Length } \\
\hline mile (mi) & 1.609 & kilometer $(\mathrm{km})$ \\
\hline \multicolumn{3}{|c|}{ Area } \\
\hline square mile $\left(\mathrm{mi}^{2}\right)$ & 2.590 & square kilometer $\left(\mathrm{km}^{2}\right)$ \\
\hline \multicolumn{3}{|c|}{ Mass } \\
\hline ton, short $(2,000 \mathrm{lb})$ & 0.9072 & megagram (Mg) \\
\hline \multicolumn{3}{|c|}{ International System of Units to Inch/Pound } \\
\hline Multiply & By & To obtain \\
\hline \multicolumn{3}{|c|}{ Length } \\
\hline kilometer (km) & 0.6214 & mile (mi) \\
\hline \multicolumn{3}{|c|}{ Area } \\
\hline square kilometer $\left(\mathrm{km}^{2}\right)$ & 0.3861 & square mile $\left(\mathrm{mi}^{2}\right)$ \\
\hline \multicolumn{3}{|c|}{ Mass } \\
\hline megagram (Mg) & 1.102 & ton, short $(2,000 \mathrm{lb})$ \\
\hline
\end{tabular}

\section{Datums}

Vertical coordinate information is referenced to the North American Vertical Datum of 1988 (NAVD 88).

Horizontal coordinate information is referenced to the Universal Transverse Mercator (UTM) map projection, using the following parameters: map units, meters; zone, 13; North American Datum of 1927 (NAD 27); and spheroid, Clarke 1866. 


\title{
Abbreviations, and Useful Websites Used in This Report
}

\author{
BLM U.S. Bureau of Land Management, http://www.blm.gov/wo/st/en.htm \\ Esri Environmental Systems Research Institute, http://www.esri.com/ \\ CERSC Central Energy Resources Science Center, \\ http://energy.usgs.gov/Generallnfo/ScienceCenters/central.aspx \\ FGDC Federal Geographic Data Committee Content Standard for Geospatial Metadata, \\ https://www.fgdc.gov/metadata \\ GIS geographic information system \\ IMS internet mapping service \\ MXD ArcMap project \\ NCRDS USGS National Coal Resources Database System, \\ http://energy.er.usgs.gov/products/databases/CoalQual/index.htm \\ PMF ArcReader project \\ PRB Powder River Basin (both Wyoming and Montana) \\ USGS U.S. Geological Survey, http://www.usgs.gov/
}





\title{
Geospatial Data for Coal Beds in the Powder River Basin, Wyoming and Montana
}

\author{
By Scott A. Kinney, David C. Scott, Lee M. Osmonson, and James A. Luppens
}

\section{Abstract}

The purpose of this report is to provide geospatial data for various layers and themes in a Geographic Information System (GIS) format for the Powder River Basin, Wyoming and Montana. In 2015, as part of the U.S. Coal Resources and Reserves Assessment Project, the U.S. Geological Survey (USGS) completed an assessment of coal resources and reserves within the Powder River Basin, Wyoming and Montana. This report is supplemental to USGS Professional Paper 1809 and contains GIS data that can be used to view digital layers or themes, including the Tertiary limit of the Powder River Basin boundary, locations of drill holes, clinker, mined coal, land use and technical restrictions, geology, mineral estate ownership, coal thickness, depth to the top of the coal bed (overburden), and coal reliability categories. Larger scale maps may be viewed using the GIS data provided in this report supplemental to the page-size maps provided in USGS Professional Paper 1809. Additionally, these GIS data can be exported to other digital applications as needed by the user. The database used for this report contains a total of 29,928 drill holes, of which 21,393 are in the public domain. The public domain database is linked to the geodatabase in this report so that the user can access the drill-hole data through GIS applications. Results of this report are available at the USGS Energy Resources Program Web site, http://energy. usgs.gov/RegionalStudies/PowderRiverBasin.aspx.

\section{Introduction and Objectives}

One of the objectives of the U.S. Geological Survey (USGS) United States (U.S.) Coal Resources and Reserves Assessment Project is to conduct regional-scale coal resource and reserve assessments of significant coal beds in major coal basins in the United States. In 2014, the USGS completed an assessment of coal resources and reserves within the Powder River Basin (PRB) in Wyoming and Montana (fig. 1). The PRB contains the largest resources of low-sulfur, low-ash, subbituminous coal in the U.S. During 2012, almost 420 million short tons were produced from this basin, which was about 42 percent of the total coal production in the U.S., making it the most important coal basin in the Nation (Luppens and others, 2015). The PRB covers about 19,500 square miles $\left(\mathrm{mi}^{2}\right)$, exclusive of the part of the basin within the Crow and Northern Cheyenne Indian Reservations in Montana.

Although the PRB has been previously assessed for coal resources by the USGS and other Federal and State agencies, no regional-scale coal reserve estimates have been published. Previous assessments did not take into consideration the amount of coal that cannot be mined because of clinker, mined coal, land-use and technical restrictions, geologic conditions, mineral estate ownership, coal thickness, depth to the top of the coal bed (overburden), coal loss due to mining, or economic constraints. Furthermore, most of the previous estimates were based on thickness of coal zones, not thickness of individual coal beds. Coal resource estimates, and especially reserve estimates, are founded on geological models of individual coal beds, not by coal zones. Therefore, developing consistent regional coal-bed stratigraphy and correlations, rather than coal zone intervals, was essential for conducting economic recoverability studies in the PRB. The U.S. Coal Resources and Reserves Assessment Project expanded the scope of past studies to include all coal beds, regardless of depth, for the entire PRB (Luppens and others, 2008).

As a foundation for the PRB assessment, the largest possible drill-hole database was assembled. The core of the digital database was provided by the USGS National Coal Resources Data System (NCRDS, http://energy.er.usgs.gov/products/ databases/CoalQual/index.htm). Additional digital data were supplied by the Wyoming State Geological Survey (http:// www.wsgs.uwyo.edu/), the Montana Bureau of Mines and Geology (http://www.mbmg.mtech.edu/), the U.S. Bureau of Land Management (http://www.blm.gov/wo/st/en.html), and a commercial database (MJ Systems 2009). Confidential drillhole data were loaned to the USGS by several mining companies operating coal mines in the PRB. These data were used in the correlation process, but were not published by the USGS. A substantial amount of new data were made available from the recent development of coalbed methane in Wyoming and Montana (Wyoming Oil and Gas Conservation Commission, http://wogcc.state.wy.us/). All drill-hole data were examined by the USGS and the lithology picks were entered into a database using StratiFact (GRG Corporation, 1998). 


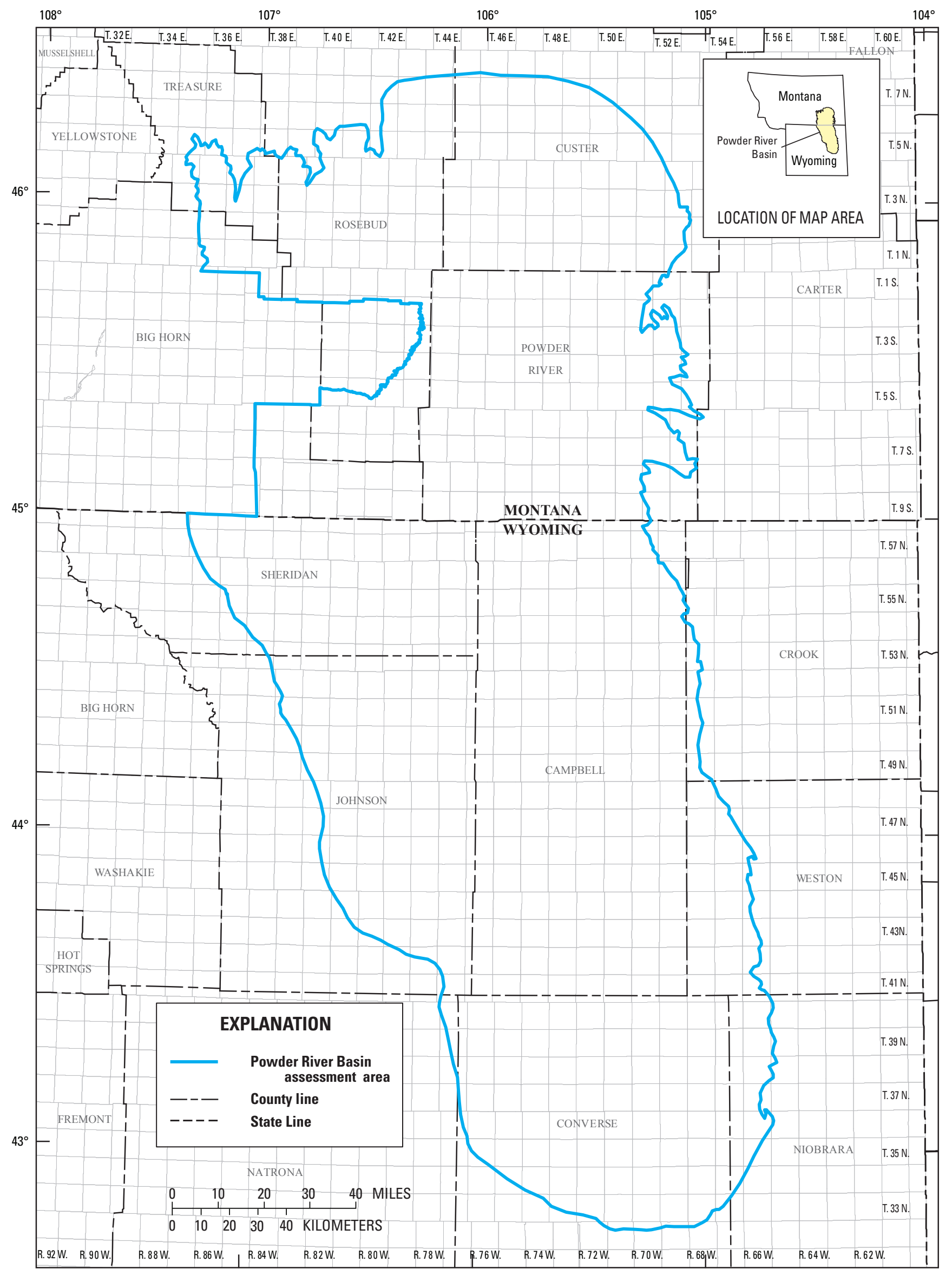

Figure 1. Location of the Powder River Basin, Wyoming and Montana. 
Correlation of all coal beds was accomplished using StratiFact software in order to place the 47 coal beds into a single stratigraphic system. Interpretations from this greatly expanded database provided a more accurate view of the coal resources and reserves in the PRB. The purpose of this report is to provide geospatial data for various layers and themes in a Geographic Information System (GIS) format for the Powder River Basin, Wyoming and Montana to supplement USGS Professional Paper 1809 (Luppens and others, 2015).

\section{Assessment Methodology}

Detailed descriptions of the methodology used for this assessment can be found in Professional Paper 1809 (Luppens and others, 2015); however, a brief description is presented in this report. A three-phase methodology for calculating coal resources and reserves in the PRB was used for Professional Paper 1809. The first phase of the assessment involved data collection and editing. Data pertaining to coal bed geology, extent and thickness of coal beds, interburden thickness, parting thickness, overburden thickness, structure, factors that affect extraction of coal, coal ownership, coal quality, coal sales price, and tax information were gathered during this phase of the assessment. Geophysical logs for 29,928 drill holes (of which 21,393 were non-proprietary) were examined and the lithology picks were entered in a database using the StratiFact software and graphics program. The database of non-proprietary drill holes was previously published by the USGS (Haacke and Scott, 2013) and is also included in this report.

The second phase of the assessment consisted of the correlation of individual coal beds, creating integrated, multicoalbed models, and creating land-use and technical restrictions to mining. Using StratiFact software, cross sections were selected and edited and correlations were completed digitally. Both linear and circular cross sections were constructed to correlate coal beds across the entire PRB. With this process, the beginning and ending drill hole of a cross section is the same, assuring that the coal beds do not intersect, thereby maintaining integrity throughout the process.

Also, within phase two of the assessment digital coalbed models were created to determine the original resources. The drill-hole data were then exported to the multi-coalbed modeling software program PC/Cores (Mentor Consultants, 2005). PC/Cores software provides a function that utilizes individual coal-bed structure grids to check for drill holes that are either too shallow to penetrate a given bed or have unlogged sections. This function allows correlations to reduce the generation of "false zero" thickness values. However, in some cases, geologic structures such as local stratigraphic highs do generate actual false zero thicknesses. PC/Cores software was then utilized to produce coal-bed models for the 47 coal beds identified in the PRB assessment. The coal resource models included coal thickness, parting thickness, roof elevation, floor elevation, and bed height. These models were then converted in the program PC/Cores to a generic ASCII data format, which were then imported into ArcView (Environmental Systems Research International (Esri), 2001). ArcView was then used to allocate coal resources by subtracting amounts of various land-use and technologic restrictions to mining (for example, mined coal, towns, clinker, national forests, alluvial valley floors) in order to calculate the amount of available coal.

The third phase of the assessment involved coal resource and reserve analysis. Coal resources were classified according to geologic assurances of existence or reliability, which are directly dependent on the density of geologic data points. The different reliability categories are:

Measured - Tonnage estimates are computed by extrapolation of thicknesses of coal for a radius of one-quarter mile (mi) (0.4 kilometers $[\mathrm{km}]$ ) from a point of measurement (Wood and others, 1983).

Indicated - Tonnage estimates are computed by extrapolation of thicknesses of coal for a radius of one-quarter to three-quarters mi (0.4 to $1.2 \mathrm{~km}$ ) from a point of measurement (Wood and others, 1983).

Inferred - Tonnage estimates are computed by extrapolation of thicknesses of coal for a radius of three-quarters to $3.0 \mathrm{mi}(1.2$ to $4.8 \mathrm{~km}$ ) from a point of measurement (Wood and others, 1983).

Hypothetical-Tonnage estimates for this category of resources are for (1) extensions of inferred resources (coal beyond a radius beyond $3.0 \mathrm{mi}(4.8 \mathrm{~km})$ from a point of measurement, and (2) regions where tonnage estimates are based on knowledge of the geologic character of coal (Wood and others, 1983).

Original, remaining, and available resources were calculated for all 47 coal beds in the PRB and were reported by reliability category, overburden category, ownership category, and assessment area. All resource and reserve estimates results can be found in U.S. Geological Survey Professional Paper 1809 (Luppens and others, 2015).

\section{Geospatial Data Description}

The USGS Central Energy Resources Science Center has developed a series of internet mapping services (IMS) to deliver GIS data to the public. This particular coal assessment and reserve interactive map project is built using Esri's ArcGIS platform and is provided as both an ArcMap project (mxd) as well as an ArcReader project (pmf). Each of these projects utilizes information from a geodatabase, which is then served graphically as geospatial layers or themes, and provides the ability to view and query layers interactively in map form. This capability in turn can facilitate the understanding of coal resources and reserves in the PRB and can aid in the formulation of energy policies on lands administered by the Federal government. These map projects geo-reference and integrate 
the geologic, geographic and spatial data to provide reference and context using a web service -based architecture. Layers or themes include: the Tertiary limit of the Powder River Basin boundary, drill holes, clinker, mined coal, technical restrictions to mining, geology, coal thickness, depth to the top of the coal bed, and coal reliability. The coal thickness, depth, and reliability data are available for each of the 47 individual coal beds that were assessed. In addition, all of the content in this report is documented based on the Federal Geographic Data Committee Content Standard for Geospatial Metadata (FGDC, https://www.fgdc.gov/metadata). Access to the metadata is provided in a variety of formats that are incorporated into the downloadable datasets.

The following sections describe data in each of the ArcMap projects. A zip file (.zip) contains both an Esri ArcMap (MXD file) and geodatabase (GDB file). Clicking the zip file will extract the folder (Coal and Geology of the Powder River Basin) to the location on a computer designated by the user. Clicking on the MXD file will initiate ArcMap (version 10.0 or higher). The data in each project are organized into two categories: Powder River Basin Base and Geology Layers, and Powder River Basin Coal Bed Layers. A description of the contents or layers of each category follows. Each layer title includes the actual name of the layer in the project as well as the geodatabase feature class name in parenthesis. Data in the layers are current as of December 2013.

\section{Powder River Basin Base and Geology Layers}

\section{Basin Boundary (prb_bndy)}

This layer contains a polygon showing the PRB boundary, based on a generalized contact between Cretaceous and Tertiary-age rocks. The basin covers about 19,500 $\mathrm{mi}^{2}$ (fig. 1). Prb_bndy is a feature class contained within the prb_pt_poly feature dataset in the prb_coal_geology geodatabase. The GIS data and metadata can be found in USGS Open-File Report 98-102 (Biewick and others, 1998) at http://pubs.usgs.gov/ of/1998/ofr-98-0102/.

\section{Drill Holes (drill_holes)}

This layer contains location information for the 21,393 public domain drill-hole database for the PRB (Haacke and Scott, 2013). The Drill Holes file is related in a one-tomany relationship to a table named prb_drill_hole_strat. This layer provides the down-hole stratigraphic data by point location. The GIS data and metadata can be found at: http://pubs. usgs.gov/ds/713/ (Haacke and Scott, 2013).

\section{Clinker (prb_area_clink)}

This layer is a polygon representing the areas of clinker within the PRB. Prb_area_clink is a feature class contained within the prb_pt_poly feature dataset in the prb_coal_geology geodatabase. Clinker is rock that has been thermally altered by natural burning of coal beds. The polygon was used to calculate the volume of clinker within the 47 coal beds in the PRB. Information for the clinker GIS data and metadata can be obtained by contacting the BLM Wyoming State Office at (http://www.blm.gov/wy/st/en.html) eheffern@blm.gov.

\section{Mined Coal (prb_prev_mine)}

This layer is a polygon of the areas of mined coal within the PRB. The polygon was used to calculate the amount of coal resource that had previously been mined within the 47 coal beds in the PRB.

\section{Mining Restrictions (prb_restric)}

This layer is a polygon created to define the surface areas within the PRB where mining is restricted because of state and federal regulations. Prb_restric is a feature class contained within the prb_pt_poly feature dataset in the prb_coal_geology geodatabase. The layer was also used to determine surface areas of each underlying coal bed that would be restricted to mining because of areal extent of these areas.

\section{Geology (prb_geology)}

This layer is a polygon that contains the generalized geology of the PRB and provides the most recent geologic coverage of the PRB. Prb_geology is a feature class contained within the prb_pt_poly feature dataset in the prb_coal_geology geodatabase. GIS data and metadata can be found at: http:// pubs.usgs.gov/pp/p1625a/ (U.S. Geological Survey Central Region Energy Resources Team, 1999).

\section{Ownership (prb_own)}

This layer is a polygon showing the subsurface mineral ownership within the PRB. Prb_own is a feature class contained within the prb_pt_poly feature dataset in the prb_coal geology geodatabase. GIS data and metadata can be found at: http://pubs.usgs.gov/of/1998/ofr-98-0102/ (Biewick and others, 1998).

\section{Powder River Basin Coal Bed Layers}

\section{Coal Thickness ("bed-name"_coal)}

Coal thickness grids were created for all 47 coal beds within the PRB. All of these raster datasets are named "bed name"_coal, where "bed name" is replaced by the abbreviated bed name, such as and_coal (and=Anderson, see the 3-letter codes in table 1). 
Table 1. List of coal bed names in chronological order, the 3-letter code used in the database, number of drill holes, and geologic formation name of the 47 coal beds in the Powder River Basin, Wyoming and Montana.

\begin{tabular}{|c|c|c|c|}
\hline Coal bed name & 3-letter code & Number of holes & Formation \\
\hline Upper Healy & hlu & 186 & Wasatch \\
\hline Healy/Lower Ulm & hly & 658 & Wasatch \\
\hline Murray & mur & 785 & Wasatch \\
\hline Ucross & ucr & 591 & Wasatch \\
\hline Upper Felix & fxu & 1,989 & Wasatch \\
\hline Felix & flx & 4,444 & Wasatch \\
\hline Lower Felix & fxl & 4,109 & Wasatch \\
\hline Roland Upper Rider & ruu & 5,710 & Fort Union \\
\hline Roland Lower Rider & rul & 1,619 & Fort Union \\
\hline Roland (Baker) & rbk & 9,987 & Fort Union \\
\hline Roland (Taff) & $\mathrm{rtf}$ & 953 & Fort Union \\
\hline Upper Smith & smu & 326 & Fort Union \\
\hline Smith & smt & 9,334 & Fort Union \\
\hline Anderson Upper Rider & auu & 343 & Fort Union \\
\hline Anderson Lower Rider & aul & 480 & Fort Union \\
\hline Anderson & and & 11,775 & Fort Union \\
\hline Lower Anderson & anl & 883 & Fort Union \\
\hline Dietz 1 & $\mathrm{dz} 1$ & 672 & Fort Union \\
\hline Dietz 2 & $\mathrm{dz} 2$ & 930 & Fort Union \\
\hline Dietz 3 & $\mathrm{dz} 3$ & 4,816 & Fort Union \\
\hline Dietz 4 & $\mathrm{dz} 4$ & 624 & Fort Union \\
\hline Upper Canyon/Cox & $\mathrm{cnu}$ & 726 & Fort Union \\
\hline Canyon & can & 9,354 & Fort Union \\
\hline Lower Canyon & $\mathrm{cnl}$ & 4,374 & Fort Union \\
\hline Upper Ferry & fru & 145 & Fort Union \\
\hline Ferry & fer & 744 & Fort Union \\
\hline Werner/Cook & wer & 4,460 & Fort Union \\
\hline Upper Otter & otu & 328 & Fort Union \\
\hline Otter & otr & 3,642 & Fort Union \\
\hline Gates/Wall & gat & 3,412 & Fort Union \\
\hline Pawnee & paw & 1,368 & Fort Union \\
\hline Brewster-Arnold & bar & 110 & Fort Union \\
\hline Odell & odl & 1,052 & Fort Union \\
\hline Cache & $\mathrm{cac}$ & 247 & Fort Union \\
\hline A Zone & azn & 24 & Fort Union \\
\hline Upper Rosebud/S1 & rdu & 44 & Fort Union \\
\hline Rosebud/Knobloch/Deep1 & rk1 & 2,206 & Fort Union \\
\hline Calvert & cal & 86 & Fort Union \\
\hline McKay/Nance/Deep2 & $\mathrm{mn} 1$ & 2,499 & Fort Union \\
\hline Lower Mckay/S2 & $\mathrm{mkl}$ & 63 & Fort Union \\
\hline Flowers-Goodale/Deep3 & fg3 & 2,752 & Fort Union \\
\hline Upper Witham & wup & 1 & Fort Union \\
\hline Robinson/Witham/Deep4 & rw4 & 1,491 & Fort Union \\
\hline Roberts/Terret & rob & 1,768 & Fort Union \\
\hline Burley & bur & 50 & Fort Union \\
\hline Upper Stag & stg & 91 & Fort Union \\
\hline Lower Stag & stl & 8 & Fort Union \\
\hline
\end{tabular}


Geospatial Data for Coal Beds in the Powder River Basin, Wyoming and Montana

\section{Depth to Top of Coal (“bed name"_ovb)}

Overburden grids (depth to top of coal) were created for the 47 coal beds within the PRB. All of these raster datasets are named "bed name"_ovb, where "bed name" is replaced by the abbreviated bed name, such as and_ovb (and=Anderson, see the 3-letter codes in table 1). These polygons were developed to determine the stripping ratios for surface mining and the depth for possible underground mining. Each overburden raster dataset represents the depth from the surface to the top of the coal bed.

\section{Reliability (“bed name”_reli)}

Coal reliability grids were created for the 47 coal beds in the PRB. All of these raster datasets are named "bed name" reli, where "bed name" can be replaced by the abbreviated bed name, such as "And_rel" (and=Anderson, see the 3-letter codes in table 1). Coal reliability categories providing relative geological assurances were based on distance from a point of measurement. Measured, indicated, inferred, and hypothetical categories indicate the reliability of tonnage estimates based on distance from a specific drill hole (Wood and others, 1983).

Measured - Tonnage estimates are computed by extrapolation of thicknesses of coal for a radius of one-quarter mile (mi) (0.4 kilometers $[\mathrm{km}])$ from a point of measurement.

Indicated - Tonnage estimates are computed by extrapolation of thicknesses of coal for a radius of one-quarter to three-quarters mi (0.4 to $1.2 \mathrm{~km}$ ) from a point of measurement.

Inferred - Tonnage estimates are computed by extrapolation of thicknesses of coal for a radius of three-quarters to $3.0 \mathrm{mi}$ ( 1.2 to $4.8 \mathrm{~km}$ ) from a point of measurement.

Hypothetical-Tonnage estimates for this category of resources are for (1) extensions of inferred resources (coal beyond a radius beyond $3.0 \mathrm{mi}(4.8 \mathrm{~km})$ from a point of measurement, and (2) regions where tonnage estimates are based on knowledge of the geologic character of coal.

Files with links indicate where metadata can be obtained, otherwise the metadata is provided in the zipped folder in the downloaded project files.

\section{The Data Package}

This report can be downloaded from the USGS Central Energy Resources Science Center (CERSC) web site or from http://pubs.usgs.gov/ds/912 or http://dx.doi.org/10.30133/ ds 912 and consists of a pamphlet and the GIS data files.

\section{Acknowledgments}

Gregory Gunther, Tracey Mercier, Jon Haacke, and David Ferderer, all of the USGS, provided in-depth technical reviews of the manuscript.

\section{References}

Biewick, L.R.H., Urbanowski, S.R., Cain, Sheila, and Neasloney, Larry, 1998, Land status and Federal mineral ownership in the Powder River Basin, Wyoming and Montana-A digital data set for geographic information systems: U.S. Geological Survey Open-File Report 98-102, available at http://pubs.usgs.gov/of/1998/ofr-98-0102/.

Bragg, L.J., Oman, J.K., Tewalt, S.J., Oman, C.J., Rega, N.H., Washington, P.M., and Finkleman, R.B., 1997, U.S. Geological Survey coal quality (COALQUAL) database; version 2.0: U.S. Geological Survey Open-File Report 97-134, http://energy.er.usgs.gov/products/databases/CoalQual/intro. htm.

Environmental Systems Research Institute, Inc., (Esri) 2001, ArcView software version 3.2a: Redlands, Calif., Esri, http://www.esri.com/.

GRG Corporation, 1998, StratiFact software version 4.57: Wheat Ridge, Colo., GRG Corporation.

Haacke, J.E., and Scott, D.C., 2013, Drill hole data for coal beds in the Powder River Basin, Montana and Wyoming: U.S. Geological Survey Data Series 713, 15 p., http://pubs. usgs.gov/ds/713.

Luppens, J.A., Scott, D.C., Haacke, J.E., Osmonson, L.M., and Pierce, P.E., 2015, Coal geology and assessment of coal resources and reserves in the Powder River Basin, Wyoming and Montana: U.S. Geological Survey Professional Paper 1809, 218 p., http://dx.doi.org/10.3133/pp1809.

Luppens, J.A., Scott, D.C., Haacke, J.E., Osmonson, L.M., Rohrbacher, T.J., and Ellis, M.S., 2008, Assessment of coal geology, resources, and reserves in the Gillette coal field, Powder River Basin, Wyoming: U.S. Geological Survey Open-File Report 2008-1202, 127 p. [Also available at http://pubs.usgs.gov/ofr/2008/1202.]

Mentor Consultants, 2005, PC/Cores: Glen Ellyn, Post Office Box 3147, Illinois. 
MJ Systems Inc., 2009, Well log library: Denver, Colo., MJ Systems Inc., accessed on June 1, 2009 at http://www.

mjlogs.com/

U.S. Geological Survey Central Energy Resources Team, 1999, 1999 resource assessment of selected Tertiary coal beds and zones in the northern Rocky Mountains and Great Plains region: U.S. Geological Survey Professional Paper $1625 \mathrm{~A}$, pages variable. [Also available at http://pubs.usgs. gov/pp/p1625a/.]

U.S. Bureau of Land Management (BLM), 2001, Coal screening process, appendix D of Approved resource management plan for public lands administered by the Bureau of Land Management Buffalo field office: Buffalo, Wyo., U.S Department of the Interior, Bureau of Land Management, Buffalo Field Office, available at http://www.blm. gov/pgdata/etc/medialib/blm/wy/programs/planning/rmps. Par.94672.File.dat/2001rmp_update.pdf.

Wood, G.H., Jr., Kehn, T.M., Carter, M.D., and Culbertson, W.C., 1983, Coal resource classification system of the U.S. Geological Survey: U.S. Geological Survey Circular $891,65 \mathrm{p}$. 
Publishing support provided by:

Denver Publishing Service Center, Denver, Colorado, and

Rolla Publishing Service Center, Rolla, Missouri

For more information concerning this publication, contact:

Center Director, USGS Central Energy Resources Science Center

Box 25046, Mail Stop 939

Denver, CO 80225

(303) 236-1647

Or visit the Central Energy Resources Science Center Web site at: http://energy.usgs.gov/

This publication is available online at: http://dx.doi.org/10.3133/ds912 



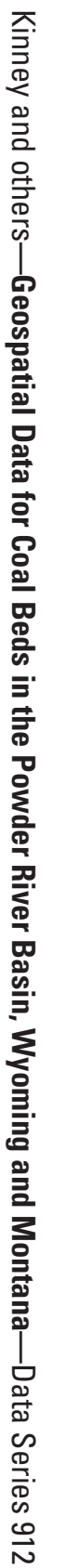

